\title{
Hubungan Pengetahuan, Sikap Dan Lama Kerja Bidan Dengan Pelaksanaan Inisiasi Menyusu Dini Di Wilayah Kerja Puskesmas Landasan Ulin
}

\author{
Eka Handayani \\ Fakultas Kesehatan Masyarakat Universitas Islam Kalimantan MAB Banjarmasin \\ email : ekabella8888@gmail.com
}

DOI: $10.33859 / \mathrm{dksm.v11i1.626}$

\begin{abstract}
Abstrak
Latarbelakang: Inisiasi Menyusu Dini merupakan salah satu upaya untuk meningkatkan cakupan ASI eksklusif. Keberhasilan program Inisiasi Menyusu Dini sangat dipengaruhi oleh pengetahuan, sikap, dan tindakan dari penolong persalinan itu sendiri, karena merekalah yang pertama kali membantu ibu selama proses persalinan. Terdapat beberapa faktor yang berhubungan dengan kinerja bidan dalam pelaksanaan Inisiasi Menyusu Dini yaitu umur, lama kerja, tingkat pendidikan, pengetahuan, sikap dan pelatihan.

Tujuan : untuk mengetahui hubungan pengetahuan, sikap dan lama masa kerja bidan dengan pelaksanaan inisiasi menyusu dini.

Metode:penelitian ini adalah kualitatif dengan pendekatan Cross Sectional. Populasi dalam penelitian ini adalah bidan yang melaksanakan pertolongan persalinan di wilayah kerja puskesmas landasan ulin sebanyak 31 responden.

Hasil: Berdasarkan uji chi square didapatkan hasil hubungan yang signifikan antara variabel pengetahuan bidan dengan pelaksanaan Inisiasi Menyusu Dini ( $\mathrm{p}$ value 0,012), Terdapat hubungan yang signifikan antara variabel sikap bidan dengan pelaksanaan Inisiasi menyusu Dini ( $p$ value 0,027), Ada hubungan yang signifikan antara variabel lama masa kerja bidan dengan pelaksanaan Inisiasi Menyusu Dini (p value 0,012).

Kesimpulam Berdasarkan hasil analisis data statistik dan pembahasan dapat disimpulkan bahwa terdapat hubungan yang signifikan antara variabel pengetahuan bidan dengan pelaksanaan IMD dengan nilai probabilitas 0,012 . Terdapat hubungan yang signifikan antara variabel sikap bidan dengan pelaksanaan Inisiasi menyusu Dini dimana nilai probabilitas 0,027 . Ada hubungan yang signifikan antara variabel lama masa kerja bidan dengan pelaksanaan Inisiasi Menyusu Dini dimana nilai probabilitas 0,012.

Kata kunci: Pengetahuan, Sikap, Lama Masa Kerja Dan Pelaksanaan Inisiasi Menyusu Dini
\end{abstract}




\begin{abstract}
Background: Early Initiation of Breastfeeding is an effort to increase coverage of exclusive breastfeeding. The success of the Early Breastfeeding Initiation program is strongly influenced by the knowledge, attitudes, and actions of the birth attendants themselves, because they are the first to help mothers during the labor process. There are several factors related to the performance of midwives in implementing Early Breastfeeding Initiation, namely age, length of work, level of education, knowledge, attitudes and training.

Objective: to determine the relationship between knowledge, attitudes and length of service of the midwife with the implementation of early breastfeeding.

Methods: This study is a qualitative study with a cross sectional approach. The population in this study were 31 midwives who delivered delivery assistance in the work area of the Puskesmas Ulin clinic.

Results: Based on the chi square test, it was found that there was a significant relationship between the knowledge variable midwives and the implementation of Early Breastfeeding Initiation ( $p$ value 0.012). variable length of service midwives with the implementation of Early Initiation of Breastfeeding ( $p$ value 0.012).

Conclusions:Based on the results of statistical data analysis and discussion, it can be concluded that there is a significant relationship between the knowledge variable of midwives and the implementation of IMD with a probability value of 0.012. There is a significant relationship between the variable attitude of midwives and the implementation of early breastfeeding where the probability value is 0.027 . There is a significant relationship between the variable length of service of midwives and the implementation of Early Initiation of Breastfeeding where the probability value is 0.012.
\end{abstract}

Keywords: Knowledge, Attitude, Length of Service Period and Early Initiation of Breastfeeding

\section{PENDAHULUAN}

ASI adalah sebuah cairan tanpa tanding ciptaan Allah SWT untuk memenuhi kebutuhan gizi bayi dan melindunginya dalam melawan serangan penyakit (Yahya, 2005). Angka pemberian ASI ekslusif di Indonesia masih tergolong rendah, pemberian ASI ekslusif di Indonesia hanya 35\%. Angka tersebut masih jauh di bawah rekomendasi WHO (Badan Kesehatan Dunia) sebesar 50\%. (Kemenkes, 2014).

Salah satu bagian yang terpenting dari pembangunan kesehatan adalah kesehatan ibu dan anak, yang merupakan indikator dari keberhasilan pembangunan nasional dibidang kesehatan. Akhir-akhir ini, dibidang kesehatan ibu dan anak semakin digalakkan tentang inisiasi menyusui dini (IMD), ASI ekslusif dan manajemen laktasi. Ketiga program ini saling berkaitan satu sama lain (Maryunani, 2012).

Dalam rangka menurunkan angka kesakitan dan kematian bayi, UNICEF dan WHO merekomendasikan sebaiknya bayi hanya disusui air susu ibu (ASI) selama paling sedikit 6 bulan, dan pemberian ASI dilanjutkan sampai bayi berumur dua tahun (WHO, 2018). 
Agar ibu dapat mempertahankan ASI eksklusif selama 6 bulan, WHO merekomendasikan agar melakukan inisiasi menyusui dalam satu jam pertama kehidupan, bayi hanya menerima ASI tanpa tambahan makanan atau minuman, termasuk air, menyusui sesuai permintaan atau sesering yang diinginkan bayi, dan tidak menggunakan botol atau dot (WHO, 2018).

Tujuan dari pembangunan kesehatan salah satunya adalah menurunkan angka kematian bayi. Angka Kematian Bayi menurut Sustainable Development Goals dalam The 2030 Agenda For Sustainable Development menargetkan pada tahun 2030 dapat mengurangi angka kematian neonatal paling sedikit 12 per 1.000 kelahiran hidup dan kematian pada anak di bawah usia 5 tahun paling sedikit 25 per 1.000 kelahiran hidup. Hal tersebut dapat dicapai salah satunya dengan pemberian ASI eksklusif dilaksanakan dengan baik (United Nations). (WHO, 2018).

Namun, hanya 44 persen dari bayi baru lahir di dunia yang mendapat ASI dalam waktu satu jam pertama sejak lahir, cakupan pemberian ASI eksklusif di Afrika Tengah sebanyak 25\%, Amerika Latin dan Karibia sebanyak 32\%, Asia Timur sebanyak 30\%, Asia Selatan sebanyak 47\%, dan negara berkembang sebanyak $46 \%$. Secara keseluruhan, kurang dari $40 \%$ anak di bawah usia enam bulan diberi ASI Eksklusif (WHO, 2015).
Penyebab kematian bayi terbesar di Indonesia adalah kematian neonatal dan dua pertiga dari kematian neonatal adalah pada satu minggu pertama dimana daya imun bayi masih sangat rendah. Angka kematian bayi yang cukup tinggi dapat dihindari dengan pemberian air susu ibu (ASI). Banyak penelitian yang dilakukan, tehnologi canggih digunakan, namun tindakan preventif yang paling ampuh dilakukan untuk menyelamatkan bayi-bayi Indonesia adalah melakukan Inisiasi Menyusui Dini (IMD) dan memberikan ASI eksklusif (Moascara, 2011).

Inisiasi Menyusui Dini (IMD) adalah proses bayi menyusu segera setelah dilahirkan dan merupakan program yang sedang gencar dianjurkan pemerintah dalam bereberapa tahun belakangan ini. IMD harus segera dilakukan langsung saat bayi lahir, tanpa boleh ditunda dengan kegiatan menimbang atau mengukur bayi. Bayi juga tidak boleh dibersihkan, hanya boleh dikeringkan kecuali tangan. Dari banyak penelitian IMD ternyata banyak manfaat. Salah satunya menyelamatkan 1 juta bayi (Maryunani, 2010)

Meskipun IMD telah diketahui banyak manfaatnya, namun pelaksanaannya tidak mudah dilakukan. Berdasarkan laporan Menkes tahun 2010 kesadaran memberikan ASI dini menunjukan grafik yang meningkat. Sepanjang tahun 2004-2008 pemberian ASI dini meningkat dari 58,9\% menjadi $62,2 \%$. Namun setelah itu grafik tidak pernah 
meningkat lagi, bahkan cendrung menurun, ternyata dengan program Inisiasi Menyusu Dini tingkat kematian bayi dapat ditekan sampai 22\% (Maryunani,2012).

Inisiasi Menyusu Dini (IMD)
merupakan salah satu upaya untuk
meningkatkan cakupan ASI eksklusif.
Berdasarkan hasil penelitian Fikawati dan Syafiq (2010) yang dikutip dari Roesli (2008), bayi yang berkesempatan melakukan IMD pada usia enam bulan sebesar 59\% masih menyusu dan bayi usia 12 bulan sebesar $38 \%$ masih menyusu. Pada bayi yang tidak diberi kesempatan IMD, pada usia enam bulan hanya 19\% yang masih menyusu dan untuk bayi berusia 12 bulan hanya $8 \%$ yang masih menyusu. Bayi yang diberi kesempatan menyusu dini akan delapan kali lebih berhasil dalam menyusu eksklusif. Berarti, bayi yang diberi kesempatan IMD akan lebih mungkin disusui sampai usia dua tahun, bahkan lebih. Dalam hal ini pengetahuan ibu tentang Inisiasi Menyusui dini, pengetahuan terutama tentang manfaat menyusui dini. Pengetahuan petugas, terutama bidan juga sangat mempengaruhi keberhasilan program IMD, dimana bidan tidak mengerti secara baik manfaat dan fungsi IMD, sehingga tidak memberikan pendidikan kesehatan kepada ibu yang baru melahirkan. Banyak ibu yang tidak mendapatkan informasi atau tidak tahu yang harus dilakukan saat pertama bayi lahir, apalagi bila pihak rumah sakit tidak mendukung dengan mengkondisikan ibu dalam melakukan inisiasi menyusui dini, sehingga ibu tidak tahu harus bersikap dalam pemberian ASI.

Keberhasilan program IMD sangat dipengaruhi oleh pengetahuan, sikap, dan tindakan dari penolong persalinan itu sendiri, karena merekalah yang pertama kali membantu ibu selama proses persalinan. Terdapat beberapa faktor yang berhubungan dengan kinerja bidan dalam pelaksanaan IMD yaitu umur, lama kerja, tingkat pendidikan, pengetahuan, sikap dan pelatihan. Setiarini (2012)

Dari latar belakang diatas peneliti tertarik meneliti "Hubungan Pengetahuan, Sikap Dan Lama Kerja Bidan Dengan Pelaksanaan Inisiasi Menyusu Dini Di Wilayah Kerja Puskesmas Landasan Ulin”.

\section{METODE}

Jenis penelitian ini adalah kualitatif dengan pendekatan Cross Sectional. Populasi dalam penelitian ini adalah bidan yang melaksanakan pertolongan persalinan di wilayah kerja puskesmas landasan ulin sebanyak 31 responden.Uji statistik menggunakan uji chi square. 
Dinamika Kesehatan Jurnal Kebidanan dan Keperawatan Vol 11 No. 1 Juli 2020 ( ISSN: 2086-3454 EISSN: 2549-4058)

url: http://ojs.dinamikakesehatan.unism.ac.id DOI : https://doi.org/10.33859/dksm.v11il

Hubungan Pengetahuan, Sikap Dan Lama Kerja Bidan Dengan Pelaksanaan Inisiasi Menyusu Dini Di Wilayah Kerja Puskesmas Landasan Ulin

HASIL

\section{Analisis Univariat}

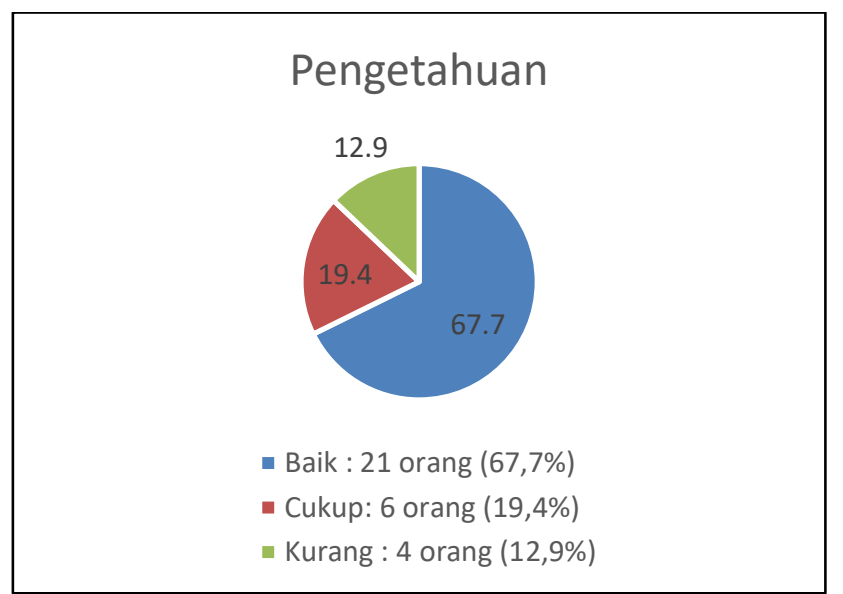

Gambar 1 Distribusi frekuensi pengetahuan bidan tentang pelaksanaan Inisiasi menyusui Dini Di Wilayah Kerja Puskesmas Landasan Ulin

Berdasarkan hasil analisis univariat yang ditunjukkan pada gambar di atas terlihat bahwa dari 31 responden sebagian besar responden mempunyai pengetahuan baik yaitu sebesar 21 orang $(67,7 \%)$ dan sebagian kecil berpengetahuan kurang baik yaitu sebesar 4 orang $(12,9 \%)$.

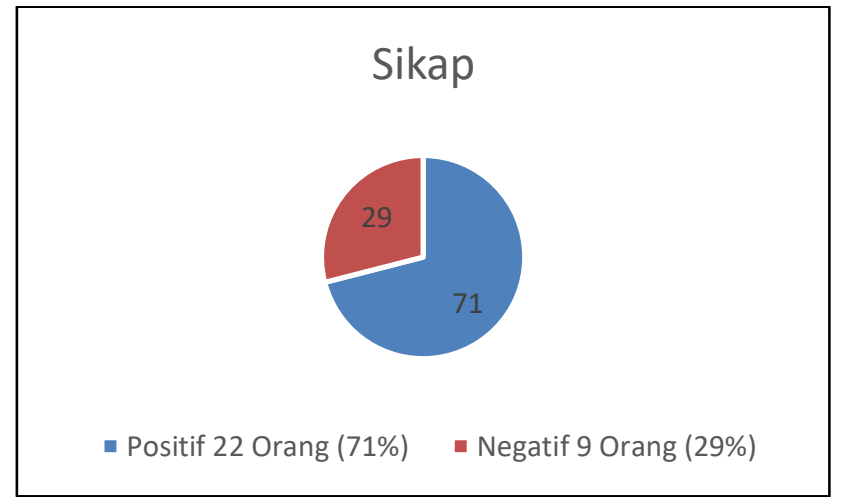

Gambar 2 Distribusi frekuensi sikap bidan tentang pelaksanaan Inisiasi menyusui Dini Di Wilayah Kerja Puskesmas Landasan Ulin
Berdasarkan hasil analisis univariat yang ditunjukkan pada gambar di atas terlihat bahwa dari 31 responden sebagian besar responden mempunyai sikap positif yaitu sebesar 22 orang (71\%) dan sebagian kecil bersikap negatif 9 orang (29\%).

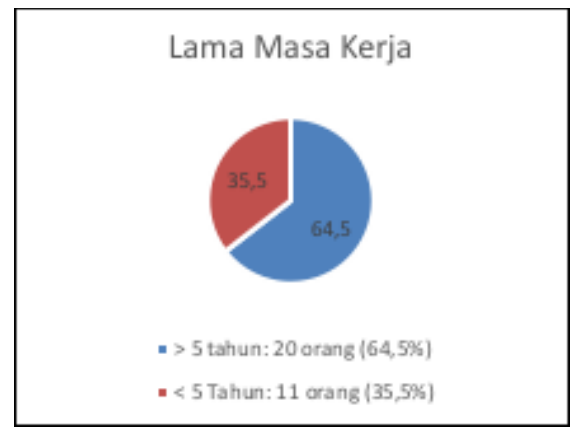

Gambar 3 Distribusi frekuensi lama masa kerja bidan tentang pelaksanaan Inisiasi menyusui Dini Di Wilayah Kerja Puskesmas Landasan Ulin

Berdasarkan hasil analisis univariat yang ditunjukkan pada gambar di atas terlihat bahwa dari 31 responden sebagian besar responden mempunyai lama masa kerja lebih dari 5 tahun positif yaitu sebesar 20 orang $(64,5 \%)$ dan sebagian kecil mempunyai lama masa kerja kurang dari 5 tahun yaitu sebesar 11 orang $(35,5 \%)$.

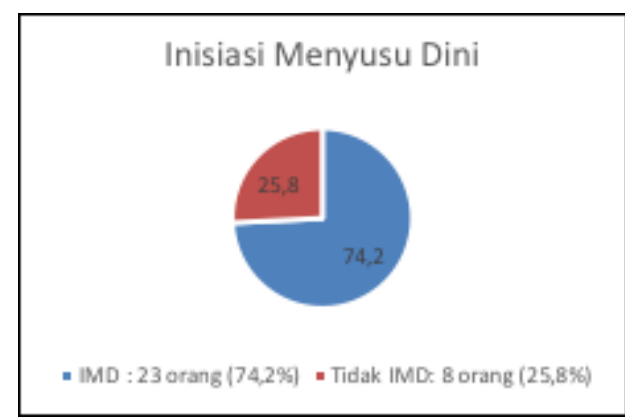

Gambar 4 Distribusi frekuensi bidan yang melakukan Inisiasi menyusui Dini Di Wilayah Kerja Puskesmas Landasan Ulin. 
Berdasarkan hasil analisis univariat yang ditunjukkan pada gambar di atas terlihat bahwa dari 31 responden sebagian besar responden menerapkan pelaksanaan inisiasi menyusu dini yaitu sebesar 23 orang $(74,2 \%)$ dan sebagian kecil tidak melakukan inisiasi menyusu dini yaitu sebesar 8 orang $(25,8 \%)$.

\section{Analisis Bivariat}

Tabel 1 Tabulasi silang Pengetahuan bidan dengan pelaksanaan Inisiasi menyusui Dini Di Wilayah Kerja Puskesmas Landasan Ulin

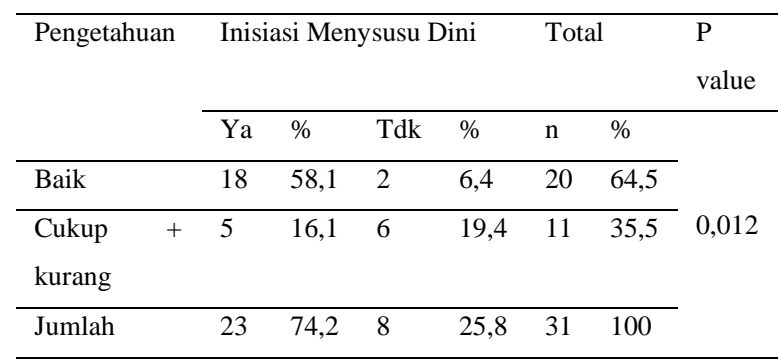

Berdasarkan tabulasi silang di atas diketahui bahwa dari 31 bidan sebagian besar responden mempunyai pengetahuan baik sebanyak 20 orang $(64,5 \%)$ dimana 18 orang $(58,1 \%)$ melakukan IMD dan 2 orang $(6,4 \%)$ tidaak melakukan IMD. Sedangkan sebagian kecil responden mempunyai pengetahuan cukup sebanyak 11 orang $(35,5)$ dimana melakukan IMD sebanyak 5 orang $(16,1 \%)$ dan yang tidak melakukan IMD sebanyak 6 orang $(19,4 \%)$

Hasil Uji chi square didapatkan nilai $\mathrm{p}$ value 0,012 , maka $p$ value $<0,05$, yang berarti terdapat hubungan yang bermakna antara pengetahuan bidan dengan pelaksanaan inisiasi menyusui dini di Wilayah Kerja Puskesmas Landasan Ulin.
Tabel 2 Tabulasi silang Sikap bidan dengan pelaksanaan Inisiasi menyusui Dini Di Wilayah Kerja Puskesmas Landasan Ulin

\begin{tabular}{lccccccc}
\hline Sikap & \multicolumn{3}{l}{ Inisiasi Menysusu Dini } & Total & $\begin{array}{l}\text { P } \\
\text { value }\end{array}$ \\
\cline { 2 - 6 } & Ya & $\%$ & Tdk & $\%$ & n & $\%$ & \\
\cline { 1 - 6 } Positif & 19 & 61,3 & 3 & 9,7 & 22 & 71 & 0,027 \\
\hline Negatif & 4 & 12,9 & 5 & 16,1 & 9 & 29 & \\
\hline Jumlah & 23 & 74,2 & 8 & 25,8 & 31 & 100 & \\
\hline
\end{tabular}

Berdasarkan tabulasi silang di atas diketahui bahwa dari 31 responden yang mempunyai sikap positif sebanyak 22 orang $(71 \%)$ yang melakukan IMD sebesar 19 orang $(61,3 \%)$ dan yang tidak melakukan IMD sebesar 3 orang $(9,7 \%)$ sedangkan yang mempunyai sikap negatif sebesar 9 orang (29\%) yang melakukan IMD sebesar 4 orang $(12,9 \%)$ dan yang tidak melakukan IMD sebesar 5 orang $(16,1 \%)$.

Hasil Uji chi square didapatkan nilai $\mathrm{p}$ value 0,027 , maka $p$ value $<0,05$, yang berarti terdapat hubungan yang bermakna antara sikap bidan dengan pelaksanaan inisiasi menyusui dini di Wilayah Kerja Puskesmas Landasan Ulin.

Tabel 3 Tabulasi silang lama masa kerja bidan dengan pelaksanaan Inisiasi menyusui Dini Di Wilayah Kerja Puskesmas Landasan Ulin

\begin{tabular}{llllllll}
\hline $\begin{array}{l}\text { Lama } \\
\text { Kerja }\end{array}$ & Masa & \multicolumn{3}{l}{ Inisiasi Menysusu Dini } & Total & $\begin{array}{l}\text { P } \\
\text { value }\end{array}$ \\
\cline { 2 - 7 } & Ya & $\%$ & Tdk & $\%$ & n & $\%$ & \\
\hline$\geq 5$ tahun & 18 & 58,1 & 2 & 6,4 & 20 & 64,5 & 0,012 \\
\hline$<5$ tahun & 5 & 16,1 & 6 & 19,3 & 11 & 35,5 & \\
\hline Jumlah & 23 & 74,2 & 8 & 25,8 & 31 & 100 & \\
\hline
\end{tabular}

Berdasarkan tabulasi silang di atas diketahui dari 31 responden yang mempunyai lama masa kerja didapatkan hasil lebih dari 5 tahun 20 orang $(64,5 \%)$ yang melakukan 
IMD sebesar 18 orang $(58,1 \%)$ dan yang tidak melakukan IMD sebesar 2 orang $(6,4 \%)$ sedangkan yang mempunyai masa kerja kurang dari 5 tahun sebesar 11 orang $(35,5 \%)$ yang melakukan IMD sebesar 5 orang $(16,1 \%)$ dan yang tidak melakukan IMD sebesar 8 orang $(25,8 \%)$.

Hasil Uji chi square didapatkan nilai $\mathrm{p}$ value 0,012 , maka $p$ value $<0,05$, yang berarti terdapat hubungan yang bermakna antara lama masa kerja bidan dengan pelaksanaan inisiasi menyusui dini di Wilayah Kerja Puskesmas Landasan Ulin.

\section{PEMBAHASAN}

1. Pengetahuan bidan dengan pelaksanaan Inisiasi menyusui Dini Di Wilayah Kerja Puskesmas Landasan Ulin.

Hasil analisis data menunjukkan dari 31 responden sebagian besar reponden mempunyai pengetahuan baik terhadap inisiasi menyusui dini yaitu sebanyak 21 orang $(67,7 \%)$, hal ini dikarenakan Tingginya pengetahuan ini mungkin disebabkan banyak faktor antara lain: pendidikan, sumber informasi, dan lingkungan, karna sebagian besar bidan sudah memiliki pendidikan D4 bidan dan banyaknya bidan yg sudah mengikuti seminar ataupun pelatihan yang berhubungan dengan inisiasi menyusu dini untuk mengupdate ilmu dan menambah keterampilan bidan.

Hal ini dipertegas oleh Notoatmodjo
(2012), yang menyatakan bahwa pengetahuan merupakan hasil tahu, setelah orang melakukan penginderaan terhadap suatu objek, dan sebagian besar pengetahuan itu diperoleh melalui mata dan telinga. Selain itu ada faktor lain yang berpengaruh terhadap pengetahuan seseorang, yaitu yang berasal dari pendidikan, pengalaman, hubungan sosial dan paparan media massa seperti majalah, TV dan buku.

Pengetahuan itu sendiri dipengaruhi oleh faktor pendidikan formal. Pengetahuan sangat erat hubungannya dengan pendidikan, dimana diharapkan bahwa dengan pendidikan yang tinggi maka orang tersebut akan semakin luas pula pengetahuannya. Akan tetapi perlu ditekankan, bukan berarti seseorang yang berpendidikan rendah mutlak berpengetahuan rendah pula. Pengetahuan seseorang tentang suatu objek mengandung dua aspek, yaitu aspek positif dan negatif. Kedua aspek ini yang akan menentukan sikap seseorang semakin banyak aspek positif dan objek yang diketahui, maka akan menimbulkan sikap makin positif terhadap objek tertentu (Dewi \& Wawan, 2010).

Hasil Uji chi square didapatkan nilai $\mathrm{p}$ value 0,012 , maka $\mathrm{p}$ value $<0,05$, yang berarti terdapat hubungan yang bermakna antara pengetahuan bidan dengan pelaksanaan inisiasi menyusui dini 
di Wilayah Kerja Puskesmas Landasan Ulin.

Hal ini sejalan dengan penelitian Sudemi, dkk tahun 2016 ada hubungan antara pengetahuan dengan pelaksanaan inisiasi menyusu dini di kabupaten Badung.

2. Sikap bidan dengan pelaksanaan Inisiasi menyusui Dini Di Wilayah Kerja Puskesmas Landasan Ulin.

Hasil analisis didapatkan dari 31 responden sebagian besar responden mempunyai sikap positif yaitu sebesar 22 orang $(71 \%)$ dan sebagian kecil bersikap negatif 9 orang (29\%). Hal ini dikarenakan sebagian besar responden mengatakan bahwa ASI lebih cepat keluar apabila dilakukanIMD dari pada ibu melahirkan yang tidak dilakukan IMD sehingga mereka sangat antusias dan bersikap positif terhadap pelaksanaan IMD.

Sikap bidan terhadap pelaksanaan IMD dinilai melalui pendapat atau pandangan bidan terhadap pernyataanpernyataan terkait pelaksanaan IMD dan manfaatnya. Hal ini didukung oleh teori Notoadmodjo 2010 dimana Sikap merupakan kesiapan untuk bereaksi terhadap objek di lingkungan tertentu sebagai suatu penghayatan terhadap objek. Sikap belum merupakan suatu tindakan atau aktivitas, akan tetapi merupakan predisposisi tindakan suatu perilaku
Sikap adalah suatu bentuk evaluasi atau reaksi perasaan. Sikap seseorang terhadap suatu objek adalah perasaan mendukung atau memihak maupun perasaan tidak mendukung atau tidak memihak pada objek tersebut (Azwar, 2008).

Hasil Uji chi square didapatkan nilai $\mathrm{p}$ value 0,027 , maka $\mathrm{p}$ value $<0,05$, yang berarti terdapat hubungan yang bermakna antara sikap bidan dengan pelaksanaan inisiasi menyusui dini di Wilayah Kerja Puskesmas Landasan Ulin.

Hasil penelitian ini sejalan dengan penelitian yang dilakukan oleh Dayati (2011) yang menunjukkan bahwa sikap bidan berhubungan dengan pelaksanaan IMD, yaitu bidan yang bersikap positif akan melaksanakan IMD secara baik.

3. Lama Kerja bidan dengan pelaksanaan Inisiasi menyusui Dini Di Wilayah Kerja Puskesmas Landasan Ulin.

Hasil analisis didapatkan dari 31 responden sebagian besar responden mempunyai lama masa kerja lebih dari 5 tahun yaitu sebesar 20 orang $(64,5 \%)$ dan sebagian kecil mempunyai lama masa kerja kurang dari 5 tahun yaitu sebesar 11 orang $(35,5 \%)$. Hal ini dapat dilihat sebagian besar responden memiliki lama masa kerja lebih dari 5 tahun dimana Inisiasi Menyusu Dini merupakan tindakan yang wajib dilakukan karena merupakan 
awal dari ASI eksklusif dimana semakin lama seseorang bekerja semakin menolong persalinan dan akan semakin sering dia melakukan penatalaksanaan IMD.

Hal ini didukung oleh Anderson (1994) yang dikutif oleh Hajrah (2012) makin lama pengalaman kerja semakin terampil seseorang, seseorang yang sudah lama bekerja mempunyai wawasan yang lebih luas dan pengalaman yang banyak yang akan memegang peranan dalam pembentukkan perilaku petugas.

Hasil Uji chi square didapatkan nilai $\mathrm{p}$ value 0,012 , maka $\mathrm{p}$ value $<0,05$, yang berarti terdapat hubungan yang bermakna antara lama masa kerja bidan dengan pelaksanaan inisiasi menyusui dini di Wilayah Kerja Puskesmas Landasan Ulin.

Hasil penelitian ini sejalan dengan penelitian Indrayani (2013) bahwa lama kerja berhubungan dengan praktik pelaksanaan IMD, bidan yang sudah bekerja $\geq 5$ tahun memiliki kecendrungan melaksanakan pelaksanaan IMD sepenuhnya 4,1 kali lebih tinggi dibandingkan yang baru bekerja.

\section{KESIMPULAN}

Berdasarkan hasil analisis data statistik dan pembahasan dapat disimpulkan bahwa terdapat hubungan yang signifikan antara variabel pengetahuan bidan dengan pelaksanaan IMD dengan nilai probabilitas 0,012. Terdapat hubungan yang signifikan antara variabel sikap bidan dengan pelaksanaan Inisiasi menyusu Dini dimana nilai probabilitas 0,027 . Ada hubungan yang signifikan antara variabel lama masa kerja bidan dengan pelaksanaan Inisiasi Menyusu Dini dimana nilai probabilitas 0,012 .

\section{DAFTAR PUSTAKA}

A, Wawan \& Dewi, 2010, Teori \& Pengukuran Pengetahuan Sikap Dan Prilaku Manusia, Yogyakarta, Nuha medika

Azwar, S., 2011. Sikap Manusia Teori dan pengukurannya, Yogyakarta, Pustaka pelajar.

Dayati. (2011). Faktor-Faktor Pada Bidan Yang Berhubungan Dengan Pelaksanaan Inisiasi Menyusu Dini (IMD) Diwilayah Kecamatan Kendari Kota Kendari Sulawesi Tenggara Tahun 2011. Depok: FKM UI.

Fikawati S, Syafiq A, 2010. Kajian implementasi dan kebijakan air susu ibu eksklusif dan inisiasi menyusu dini di Indonesia. Jurnal Makara seri Kesehatan.

Hajrah. 2012. "Faktor-faktor yang Berhubungan dengan Perilaku Bidan dalam Pelaksanaan Inisiasi Menyusu Dini (IMD) di Kabupaten Berau Tahun 2012" (Skripsi). Depok: Fakultas Kesehatan Masyarakat UI. 
Indrayani, Eka dan Mahkota, R. 2013. "Faktorfaktor yang Berhubungan dengan Praktik Pelaksanaan Inisiasi Menyusu Dini oleh Bidan di Kota Palangka Raya Provinsi Kalimantan Tengah tahun 2013" (Jurnal). Depok: UI

Kementrian Kesehatan RI. (2015). Profil Kesehatan Indonesia 2014. Jakarta: Kementerian Kesehatan Republik Indonesia.

Maryunani, Anik 2012, Inisiasi Menyusu Dini dan Manajemen Laktasi. Jakarta:: Trans Info Media

Moascara.2011.Manfaat ASI untuk Bayi, Ibu dan Keluarga. Program Manajemen Laktasi. Perkumpulan Perinatologi Indonesia. Jakarta

Notoatmodjo, Soekidjo. 2012. Promosi Kesehatan dan Prilaku Kesehatan, Jakarta : Rineka Cipta

Roesli, Utami. Inisiasi Menyusu Dini Plus ASI Eksklusif. Pustaka Bunda.Jakart. 2008

Setiarini, T. 2012. "Faktor-faktor yang Berhubungan dengan Kinerja Bidan 10 dalam pelaksanaan Insisiasi Menyusu Dini di RSIA Budi Kemuliaan Jakarta” (Tesis). Depok: Fakultas Kesehatan Masyarakat UI.

Sudemi, 2016. Hubungan Pengetahuan dan Sikap Bidan dengan Pelaksanaan Inisiasi Menyusu Dini di Kabupaten Badung. Bali:Bagian Ilmu Kedokteran Komunitas dan Ilmu Kedokteran Pencegahan Fakultas Kedokteran Universitas Udayana
World Health Organization (WHO). 2015. Advocacy Strategy Breastfeeding Advocacy Initiative For The Best Start In Life. (online) (http://www.who.int/nutrition/public a tions/infantfeeding/breastfeeding_ad vocacy_initiative/en/).

World Health Organization (WHO). 2018. The World Health Organizations Infant Feeding Recomendation. (online). (http://www.who.int/nutrition/topics Li nfantfeeding_recommendation/en/).

Yahya. 2005. Cairan Ajaib Air Susu Ibu. Jakarta: Medika 